\title{
Discretionary Loan Loss Provisions And Earnings Management For The Banking Industry
}

Ruey-Dang Chang, (Email: raychang@mail.nsysu.edu.tw), National Sun Yat-Sen University, Taiwan

Wen-Hua Shen, (Email: js1216@ms6.hinet.net), National Sun Yat-Sen University, Taiwan

Chun-Ju Fang, (Email: fcj@thu.edu.tw), Tunghai University, Taiwan

\begin{abstract}
The purpose of the study is to investigate the relation between discretionary loan loss provisions and 6 indicators of bank operating performance for the period 1999-2004 under controlling the type of bank, ownership status and asset size. Besides, we investigate whether bank managers intend to use discretionary loan loss provisions as a means for earnings management. Based on the empirical results from the Taiwan Economic Journal (TEJ) database, the study finds: (1) the two earnings-related variables, namely earnings before loan loss provisions and one-year-ahead earnings, are significantly related to discretionary loan loss provision; (2) non-performing loans is significantly related to discretionary loan loss provisions, but non-performing loans ratio and bad debts coverage ratio are not found to be significantly linked to discretionary loan loss provisions; (3) capital adequacy ratio is not significantly related to discretionary loan loss provisions. Finally, our findings indicate that bank managers may use discretionary loan loss provisions to engage in earnings management when the earnings before loan loss provisions or non-performing loans are at a high level.
\end{abstract}

Keywords: Earnings Management, Discretionary Loan Loss Provisions, Non- Performing Loans Ratio, Capital Adequacy Ratio

\section{INTRODUCTION}

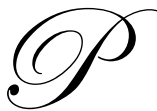

rior research generally concludes that managers engage in earnings management for many reasons and probably exercise their accounting discretion to influence reported earnings. First, they manipulate earnings because of capital market incentives, including implementing management buyouts plan, initial public offerings (IPO), seasoned equity offerings and mergers plan, to meet earnings forecasts or to smooth income, etc. Second, they implement earnings management because of contracts motivation (e.g. management compensation plans, debt agreement or job preservation). Third, they conduct earnings management due to regulation motivation, such as import regulation, industry regulation and antitrust law, etc. Regardless of whichever causes managers to manipulate earnings, the behavior of earnings management implies conflict of interest between managers, owners, and minority shareholders.

The bank managers, like managers in other industries, have incentives to "adjust" earnings and maximize bank and/or manager's wealth. The only difference is the method used to engage in earnings management. Unlike managers in other industries, bank managers usually utilize loan loss provisions to influence earnings reported. Collins et al. (1995) examine the impact of individual bank's changing levels of capital, earnings and taxes on decisions to engage in some capital-raising options. They expect low levels of nondiscretionary current earnings will encourage managers to realize investment security gains as well as decrease loan loss provisions and conclude a positive relation between earnings and loan loss provisions. Shrieves and Dahl (2003) also indicate bank managers intend to realize short-term security gains or losses and utilize loan loss provisions to smooth earnings.

Prior research documents that banks intend to execute transactions and manage accruals to achieve primary capital, tax, and earnings goals (Moyer, 1990; Scholes et al., 1990; Collins et al., 1995). In practice, banks' managers may attempt to manipulate earnings and capital because of compensation plan and/or job preservation. Just like 
other industries, earnings (including tax consideration) is one of the most important indicator in performance measurement for bank managers. In addition to earnings, non-performing loan ratio and capital adequacy ratio (hereafter, capital ratio) are the other two key indices to measure manager's performance. Hence, under compensation incentive and job preservation consideration, they will endeavor to improve earnings, raise capital ratio and keep non-performing loans ratio below standard level in order to meet their goals. Once they cannot reach the target, they may use accruals, loan loss provisions, loan charge-offs, realization of gains or losses of securities or miscellaneous gains and losses to "adjust" the figures of earnings, capital ratio and non-performing loans ratio. In practice, bank managers have discretionary powers to influence the level of loan loss provisions. Collins et al. (1995) and Anandarajan et al. (2007) find that the loan loss provisions are further used to manage earnings. Once bank managers raise the level of loan loss provisions, the second tier capital and capital ratio will increase through loan charge-offs process accordingly. In prior related studies, they employed discretionary loan loss provisions to examine earnings-smoothing motivation ( Kanagaretnam et al., 2003; Kanagaretnam et al., 2004), signal effect (Ahmed et al., 1999; Kanagaretnam et al., 2004; Eng and Nabar, 2007), the influence of bonus schemes on accounting decisions (McNichols and Wilson, 1988) or the motivation of capital management (Beatty et al., 1995; Ahmed et al., 1999).

In order to examine whether bank mangers use discretionary loan loss provisions to adjust earnings, we first construct bad debts estimation model according to the model developed by McNichols and Wilson (1988). Then we view the regression residual as discretionary loan loss provisions estimation and use the estimated discretionary loan loss provisions as a proxy of earnings management. We conjecture (1) a significant positive relation between discretionary loan loss provisions and two earnings-related variables (i.e. earnings before loan loss provisions and one-year-ahead earnings); (2) a significant positive relation between discretionary loan loss provisions and three bad-debts-related variables (i.e. non-performing loans, non-performing loan ratio and bad debts coverage ratio). But we expect a negative relation between discretionary loan loss provisions and capital adequacy ratio.

The remainder of our paper is organized as follows. Section 2 presents prior research and hypotheses development. In Section 3, we describe sample and data selection. Section 4 presents and discusses the results. Then we conclude this paper in Section 5.

\section{LITERATURE REVIEW AND HYPOTHESIS DEVELOPMENT}

\section{Prior Research}

Watts and Zimmerman (1978) assume that individuals act to maximize their own utility. So managers may lobby on accounting standards based on their own self-interest. They elaborate on the factors, namely, taxes, regulation, management compensation plans, bookkeeping cost and political costs, which are expected to affect firm's cash flows. Among those factors, regulation (represents government intervention) may affect a firm investment-production decisions and cause a firm to manage its reported earnings. Schipper (1989) states earnings management as "disclosure management" in the sense of a purposeful intervention in the external financial reporting process, with the intent of obtaining some private gains. The statement of earnings management is based on a view of accounting numbers as information. It could occur in any part of the external disclosure process and could take a lot of forms.

A large number of studies investigate managers' decision for evidence of earnings management, including choice as to accounting methods, changes in methods, and accrual strategies (Healy, 1985; Dechow and Sloan, 1991; Lewellen et al., 1996; Bernard and Skinner, 1996). Healy and Wahlen (1999) indicate that "if financial reports are to convey managers' information on their firms' performance, standards must permit managers to exercise judgment in financial reporting." It means that managers have the right to determine accounting methods, accrual choices and other accounting items which may influence reported earnings. Under accounting flexibility within GAAP, managers can use their private information and knowledge about the business to select reporting methods, estimates, and disclosures that can match their benefits.

In addition to studies about accounting choices for firms in non-bank industries, several papers have examined managerial discretion in financial service firms with respect to loan loss provisions and the sale of investments (e.g., Moyer, 1990; Scholes et al., 1990; Collins et al., 1995; Beatty et al., 1995). They focus on discretionary behavior motivated by earnings, capital adequacy management, and tax management. But what do 
bank managers exactly do to engage in earnings management? As literature documented, they may use accounting choices, timing of recognition of bad debts, sale of securities and / or discretionary accruals to influence reported earnings. For example, Clinch and Magliolo (1993) find bank managers may use discretionary behavior including the recognition of sales to influence earnings. Shrives and Dahl (2003) find that, under the Basel Accord, Japanese banks may exploit gains on securities sales and loan loss provisions to smooth reported earnings and replenish regulatory capital. Ahmed et al. (1999) find bank managers intend to use loan loss provisions for capital management. Additionally, they find negative relation between loan loss provisions and future earnings changes.

\section{Hypothesis Development}

Several studies suggest that the signaling incentive may play an important role in bank's loan loss provisions decision (Griffin and Wallach, 1991; Liu, 1995). In practice, in order to reflect real status of loans and also comply with regulation, it is a necessary process for banks to recognize loan loss for potential uncollectible loans. Liu and Ryan (1995) suggest that bank managers have more discretion over loss provisions for large and frequently renegotiated loans, such as foreign and commercial loans, than for small or infrequently renegotiated loans, e.g. consumer loans, and find that market reaction to loan loss provisions is positive for banks with a high portion of large and frequently renegotiated loans. Besides, Elliot et al. (1991) and Wahlen (1994) find that market reacts positively to bank's loan loss provisions announcements and unexpected loan loss provisions, respectively. As bank managers can arbitrarily decide the timeliness of loan loss provisions during the year, they can make use of loan loss provisions to influence reported earnings. Greenawalt and Sinkey (1988) find positive relationship between loan loss provisions and operating income before provision of loan losses and indicate that bank managers tend to engage in income smoothing behavior. When actual earnings are far lower (higher) than expected earnings, managers may make use of underestimating (overestimating) the amount of potential uncollectible loans on purpose and decrease (increase) the provision of loan losses in order to smooth earnings. Collins et al. (1995) document that heterogeneity among bank's capital, earnings, and tax strategies is linked to size, growth and profitability. They find that profitable banks may use loan loss provisions to manage earnings. We hypothesize as follows:

$\mathbf{H}_{1 \mathbf{a}}$ : Ceteris paribus, banks with higher earnings before loan loss provisions report relatively larger discretionary loan loss provisions.

The provision of loan losses in the banking industry is primarily based on requirement of regulation in Taiwan. In accordance with relative regulations, bank managers must classify loans into five categories based on risk assessment, and then use the predetermined proportion to calculate the amount of the provision for potential loan losses per month. Ceteris paribus, once bank managers decide to raise the amount of loan loss provisions substantially in current year, it means that the amount of loan loss provisions possibly will decrease considerably and cause earnings improvement next year. Wahlen (1994) indicates that when future cash flow prospects improve, bank managers may raise the discretionary component of unexpected loan loss provisions. They find a positive relation between annual unexpected provisions and future changes in cash flows as far as three years ahead. Beaver and Engel (1996) adopt the concept of signaling motivation and follow Wahlen (1994) to incorporate one-year-ahead and two-year-ahead earnings in the model to estimate discretionary portion of the allowance account. They view discretionary allowance as a signal for better future earnings and expect a positive relation between them. But Ahmed et al. (1999) provide no evidence of earnings management through loan loss provisions. They find that loan loss provisions are negatively related to both future earnings changes and contemporaneous stock returns. As the literature provides different results about the relation between loan loss provisions and future earnings, we test the relation between year-ahead-earnings and loan loss provisions and expect that higher year-ahead-earnings are associated with high level of loan loss provisions in current year. We hypothesize as follows:

$\mathbf{H}_{1 \mathbf{b}}$ : Ceteris paribus, banks with higher year-ahead-earnings report relatively larger discretionary loan loss provisions.

According to the Basel Capital Accord, the capital ratio is calculated using the definition of regulatory capital and risk-weighted assets and used by regulators to measure bank capital adequacy. The capital ratio must be no lower than 8\% (Collins et al., 1995; Basel Committee on Banking Supervision, 2004). One of the purposes for banks to manage capital is to maintain the capital ratio above the minimum of $8 \%$. The authorities will limit the bank's activities when its capital ratio can't reach the minimum requirement. Accordingly, inadequate capital ratio will bring banks unnecessary controlling costs. Moyer (1990) finds that bank managers intend to select accounting 
procedures to raise capital ratio to avoid additional controlling costs. Beatty et al. (1995) provide evidence of negative relation between loan loss provisions and capital ratio. Collins et al. (1995) expect that the calculation of the primary capital ratio indicates capital is augmented by increasing the loan loss provisions and/or decreasing loan charge-offs, but empirically find banks with low capital appear to decrease discretionary loan loss provisions for capital ratio consideration. As capital ratio plays an important role as an indicator to reflect the risk status of the bank, it indicates bank's abilities to survive under current capital structure and implies the invisible risk of default. Lin and Chen (1997) refer to the study of Liu (1985) and indicate banks with inadequate capital ratio may use discretionary loan loss provisions to augment capital ratio. Although Ahemd et al. (1999) suggest that after implementing the new Basel Capital Accord, the negative relation between loan loss provisions and capital management has decreased. Chen (2002) documents that commercial banks in Taiwan still exploit loan loss provisions to influence capital and raise capital ratio. As prior studies have examined the behavior of capital management using loan loss provisions, we test whether banks with higher capital ratio report less discretionary loan loss provisions and hypothesize as follows:

$\mathbf{H}_{2}$ : $\quad$ Ceteris paribus, banks with higher capital ratio report relatively larger discretionary loan loss provisions.

According to the regulations in Taiwan, non-performing loans mainly refer to all loans in the portfolio more than 3 months overdue on interest or principal payments, or the loans less than 3 months overdue but banks sued debtors for default already, or took legal action to disposal collateral. Under the pressure from authorities and market, bank managers may be forced to increase the provision of loan losses. Once managers increase discretionary loan loss provisions, the other performance indicators, such as earnings, non-performing loans ratio and capital ratio, will be impacted. Therefore, when bank managers decide to increase discretionary loan loss provisions this year and then write off the uncollectible loan accordingly, it will cause decreasing in both earnings and non-performing loans ratio at the same time. When the earnings after loan loss provisions still remain positive, the loan charge-offs will reduce the amount of risk-weighted assets in portfolio, then enhance the capital ratio. On the contrary, when loan loss provisions cause a large number of losses in net income, it will cause the decrease of both capital and risk-weighted assets simultaneously and lower capital ratio if the magnitude of the reduction in capital is more than risk-weighted. Similarly, when bank managers implement loan loss provisions according to real risk status and the rules of relative regulation completely, the discretionary loan loss provisions will approach zero, and won't affect earnings, non-performing loans ratio and capital ratio anymore.

In view of the long-term performance, bank managers may prefer to increase discretionary loan loss provisions in order to improve the quality of assets and lower the non-performing loans ratio in the future. They may sacrifice earnings this year to exchange for better performance next year, if they expect that it is unable to achieve the goals this year. But in view of the short performance, bank managers may be compelled to decrease loan loss provisions because of compensation plans and job preservation motivation. Namely, it will overstate reported earnings or understate negative net income. Therefore, the magnitude of discretionary loan loss provision may be affected by some key indicators with respect to performance measurement. We expect the amount and ratio of non-performing loans may influence managers' will to increase or decrease discretionary loan loss provisions. Therefore, we hypothesize as follows:

$\mathbf{H}_{3 \mathbf{a}}$ : Ceteris paribus, banks with higher non-performing loans report relatively larger discretionary loan loss provisions.

$\mathbf{H}_{3 \mathbf{b}}$ : $\quad$ Ceteris paribus, banks with higher non-performing loans ratio report relatively larger discretionary loan loss provisions.

The level of non-performing loans ratio indicates the general quality of loans portfolio. The downward trend in non-performing loans ratio means the quality of total loans has been improving and vice versa. As non-performing loans ratio is calculated by dividing non-performing loans by total loans, high non-performing loans ratio means that a relatively large number of interests and principals will be uncollectible. Other than non-performing loans ratio, another ratio, namely bad debts coverage ratio, indicates the proportion of allowance for bad debts in potential uncollectible loans. When the bad debts coverage ratio reaches $100 \%$, it means that the bank has already prepared for all the potential uncollectible loans. Once the potential uncollectible loans have been confirmed as "real" bad debts, banks will accordingly write off the bad debts. As the level of bad debts coverage ratio represents bank managers' attitude to risk, banks with higher bad debts coverage ratio may remain same policies on potential uncollectible loans. Therefore, the hypothesis is established as follows: 
$\mathbf{H}_{3 \mathbf{c}}$ : Ceteris paribus, banks with higher bad debts coverage ratio report relatively larger discretionary loan loss provisions.

\section{RESEARCH DESIGN}

A large number of papers examine managers' accrual choice to detect earnings management (Healy, 1985; Bernard and Skinner, 1996). The goal of discretionary accrual models is to separate total accruals (hereafter, TA) into discretionary and nondiscretionary components. Because discretionary accruals (hereafter, DA) are unobservable, we follow McNichols and Wilson (1988) and use proxy (DAE) to measure DA with error $(\eta)$, wherenis assumed to be white noise. As DAE equals to TA deducting an estimate of nondiscretionary accruals

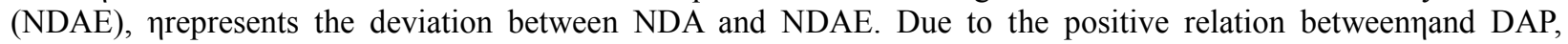
researchers usenas DA's surrogate. Therefore, we use the residual of loan loss provisions model to estimate discretionary loan loss provisions.

\section{Sample Selection}

Our data come from TEJ (Taiwan Economic Journal) which contains various data of public companies listed in the Taiwan Stock Exchange. We select 1999 through 2004 as the period of analysis and obtain 164 firm-year observations. The empirical analysis involves a two-step procedure. First, the provision of loan losses is modeled as a linear function of loan charge-offs and beginning balance of allowance for bad debts. The estimated residuals from the first-stage regression provide the estimate of discretionary loan loss provisions used in the second stage as dependable variable.

\section{Model of Loan Loss Provisions}

We estimate loan loss provisions with a set of variables including loan charge-offs and beginning balance of allowance for bad debts. McNichols and Wilson (1988) use estimated residuals of bad debts regression model as a surrogate of discretionary accruals. Loan loss provisions equal to the sum of the ending balance of allowance for bad debts and loan charge-offs, then deducting the beginning balance of allowance for bad debts. In practice, most bank managers decide the amount of loan loss provisions every month according to individual risk assessment on potential uncollectible loans and loans write-offs. Accordingly, we use the following regression to estimate loan loss provisions, and treat regression residuals as discretionary loan loss provisions:

$L L P_{t}=\beta_{0}+\beta_{1} C O_{t}+\beta_{2} B_{-} B A L_{t}+\varepsilon_{t}$

Where:

$L L P_{t}$ : loan loss provisions in year $\mathrm{t}$

$\mathrm{CO}_{t}$ : loan charge-offs in year $\mathrm{t}$

$B \_B A L_{t}$ : the beginning balance of allowance for bad debts

$\varepsilon_{t}:$ residuals

$t$ : year

\section{Model Of Discretionary Loan Loss Provisions}

Since discretionary loan loss provisions cannot be directly observed, it is estimated by regressing loan loss provisions on the explanatory variables in Eq. (1). The residual from Eq.(1) is taken to be an estimate of discretionary loan loss provisions. We regress the explanatory variables, namely earnings before loan loss provisions, one-year-ahead earnings, non-performing loans, non-performing loans ratio and bad debts coverage ratio, and test our hypotheses by estimating the coefficients in the following model.

$$
\begin{aligned}
D L L P_{t}= & \gamma_{0}+\gamma_{l} G O V E R N_{t}+\gamma_{2} C A T A_{t}+\gamma_{3} \operatorname{lnASSET}+\gamma_{4} B P \_E A R N_{t}+\gamma_{5} E A R N_{t+1}+\gamma_{6} B I S_{t}+\gamma_{7} R \_N P L_{t t}+\gamma_{8} N P L_{t} \\
& +\gamma_{9} R_{-} \text {COVER }_{t}+\varepsilon_{t}
\end{aligned}
$$


Where:

$D L L P_{t}$ : discretionary loan loss provisions in year $\mathrm{t}$

GOVERN $_{t}$ : an indicator variable equal to 1 when the bank's ownership is controlled mainly by government and 0 otherwise

$C A T A_{t}:$ an indicator variable equal to 1 when the bank is classified as a commercial bank and 0 otherwise

$\ln A S S E T_{t}$ : natural logarithm of total assets at the end of year $\mathrm{t}$

$B P \_E A R N_{t}$ : earnings before loan loss provisions at the end of the year

$E A R N_{t+1}$ : one-year-ahead earnings, i.e. earnings in year $\mathrm{t}+1$

$B I S_{t}$ : capital ratio at the end of year $\mathrm{t}$

$N P L_{t}$ : total non-performing loans in year $\mathrm{t}$

$R_{-} N P L_{t}$ : non-performing loans ratio at the end of year $\mathrm{t}$

$R_{-} C O V E R_{t}$ : bad debts coverage ratio (i.e. loan loss provisions at the end of year t over total non-performing loans)

$t$ : year

We follow Wahlen (1994), Collins et al. (1995), Ahmed et al. (1999) and Kanagaretnam et al. (2004) using discretionary loan loss provisions as response variable to test our hypotheses. The five explanatory variables in Eq.(2), namely BP_EARN ${ }_{t}, E_{A R N}{ }_{t+1}, N_{L}, R_{-} N_{2} L_{t}$, and $R_{-}$COVER $_{t}$ are added to the model to test our hypotheses. BP_EARN $_{t}$ equals to bank's earnings before loan loss provisions at the end of the year. We calculate BP_EARN $\mathrm{t}_{\mathrm{t}}$ by summing the provisions of loan losses and earnings before taxes, and divide loan loss provisions at the end of the year by total non-performing loans to compute $\mathrm{R}_{-} \mathrm{COVER}_{\mathrm{t}}$. As to $\mathrm{EARN}_{\mathrm{t}+1}, \mathrm{NPL}_{\mathrm{t}}$ and $\mathrm{R}_{-} \mathrm{NPL}_{\mathrm{t}}$ they are collected directly from TEJ database.

In addition, we include several factors that are likely to affect bank managers' discretionary loan loss provisions. First, the bigger the company is, the larger the agency problem may be (Gabor, 1985). The natural logarithm of total assets (lnASSET ${ }_{t}$ ) is included because large banks have more resources as well as abilities to make profits and hence are more likely to avoid using discretionary loan loss provisions to manipulate earnings. Second, Betty et al. (2002) find that publicly listed banks may use discretionary loan loss provisions and realization of securities gains to avoid earnings decrease. It implies that the ownership structure may influence managers' behavior of loan loss provisions. We indicate GOVERN $\mathrm{t}_{\mathrm{t}}$ as 1 if the government is the controlling owner of the bank and has the right to nominate the chairman of board, and 0 otherwise. Finally, As the type of bank exhibits different business activities and assets portfolio, we include $\mathrm{CATA}_{\mathrm{t}}$, an indicator variable equal to 1 if the bank is classified to the group of commercial banks and 0 otherwise, in Eq.(2).

\section{EMPIRICAL ANALYSIS}

\section{Descriptive Statistics For Sample}

Table 1 presents sample distribution according to year, $\mathrm{CATA}_{\mathrm{t}}$ and GOVERN $\mathrm{G}_{\mathrm{t}}$. Our sample firms report that the state-owned banks and non-state-owned banks are about 30\% and 70\% respectively. Approximately $76 \%$ of the sample banks belong to the group of commercial banks. Table 2 shows that $64 \%$ of the sample are non-state-owned commercial banks and $12 \%$ are state-owned commercial banks.

Table1: Sample Distribution

\begin{tabular}{|c|c|c|c|c|c|c|}
\hline \multirow[b]{2}{*}{ Year } & \multicolumn{2}{|c|}{ Owner Status } & \multirow[b]{2}{*}{ Total } & \multicolumn{2}{|c|}{ Type } & \multirow[b]{2}{*}{ Total } \\
\hline & $\begin{array}{l}\text { State- } \\
\text { Owned }\end{array}$ & $\begin{array}{c}\text { Non- } \\
\text { State-Owned }\end{array}$ & & $\begin{array}{c}\text { Commercial } \\
\text { Banks }\end{array}$ & Other Banks & \\
\hline 1999 & 0 & 3 & 3 & 3 & 0 & 3 \\
\hline 2000 & 9 & 24 & 33 & 26 & 7 & 33 \\
\hline 2001 & 10 & 23 & 33 & 25 & 8 & 33 \\
\hline 2002 & 10 & 23 & 33 & 25 & 8 & 33 \\
\hline 2003 & 10 & 21 & 31 & 23 & 8 & 31 \\
\hline 2004 & 10 & 21 & 31 & 23 & 8 & 31 \\
\hline Total & 49 & 115 & 164 & 125 & 39 & 164 \\
\hline
\end{tabular}


Table 2: Sample Classification

\begin{tabular}{|c|c|c|c|}
\hline Owner Status & $\begin{array}{c}\text { Commercial Banks } \\
(\mathbf{\%})\end{array}$ & Non-Commercial Bank (\%) & Total \\
\hline Non-State-Owned & $105(64 \%)$ & $10(6 \%)$ & $115(70 \%)$ \\
\hline State-Owned & $20(12 \%)$ & $29(18 \%)$ & $49(30 \%)$ \\
\hline Total & $125(76 \%)$ & $39(24 \%)$ & $164(100 \%)$ \\
\hline
\end{tabular}

\section{Regression Result}

First, we incorporate those potential decision-influencing factors ${ }^{1}$ documented in prior research in the regression model. We check scatter plot and coefficient significance of each variable, and finally select both loan charge-offs and the beginning balance of allowance for bad debts as explanatory variables to estimate the bank's provision of loan losses. Table 3 reports the descriptive statistics of loan loss provisions $\left(\right.$ LLP $\left._{t}\right)$, the beginning balance of allowance for bad debts $\left(\mathrm{B} \_\mathrm{BAL} \mathrm{L}_{\mathrm{t}}\right)$ and loan charge-offs $\left(\mathrm{CO}_{\mathrm{t}}\right)$.

Table 3: Descriptive Statistics of the Variables in Eq.(1)

\begin{tabular}{|c|c|c|c|c|c|}
\hline & Sample Size & Minimum & Maximum & Mean & S.D. \\
\hline LLP $_{\mathrm{t}}$ & 164 & -0.7 & 52.41 & 5.31 & 7.48 \\
\hline $\mathrm{B} \_B A L_{t}$ & 164 & 0.11 & 21.19 & 4.29 & 3.76 \\
\hline $\mathrm{CO}_{\mathrm{t}}$ & 164 & 0.00 & 52.57 & 5.67 & 7.67 \\
\hline
\end{tabular}

$\mathrm{LLP}_{\mathrm{t}}$ : loan loss provisions in year $\mathrm{t}$

units: NT\$100 millions

B_BAL : beginning balance of allowance for bad debts in year $t$

$\mathrm{CO}_{\mathrm{t}}$ : loan charge-offs in year $\mathrm{t}$

In Table 3, the standard deviation of those variables, especially for $\mathrm{LLP}_{\mathrm{t}}$ and $\mathrm{CO}_{\mathrm{t}}$, is relatively large compared with mean. It exhibits a substantial divergence between banks' behavior of loan loss provisions and loan charge-offs and implies different level of pressure born by every individual bank. Table 4 represents the correlation between variables.

Table 4: Correlation Coefficient between Variables in Eq.(1)

\begin{tabular}{|c|l|c|c|}
\hline Variables & LLP $_{\mathbf{t}}$ & B_BAL $_{\mathbf{t}}$ & CO $_{\mathbf{t}}$ \\
\hline $\mathrm{LLP}_{\mathrm{t}}$ & 1.000 & & \\
\hline $\mathrm{B}_{-} \mathrm{BAL}_{\mathrm{t}}$ & $0.567^{* * * * *}$ & 1.000 & 1.000 \\
\hline $\mathrm{CO}_{\mathrm{t}}$ & $0.973^{* * * * * *}$ & $0.633^{* * *}$ & \\
\hline
\end{tabular}

Significant at the $1 \%$ level; ${ }^{* *}$ Significant at the 5\% level; ${ }^{*}$ Significant at the $10 \%$ level See Table 3 for variable definitions.

In Table 4, we find that the correlation coefficient between $\operatorname{LLP}_{\mathrm{t}}$ and $\mathrm{CO}_{\mathrm{t}}$ is $0.973(\mathrm{p}<0.01)$ and the correlation between $\mathrm{LLP}_{\mathrm{t}}$ and $\mathrm{B} \_\mathrm{BAL} \mathrm{L}_{\mathrm{t}}$ is $0.567(\mathrm{p}<0.01)$. It indicates that both $\mathrm{B} \_\mathrm{BAL}_{\mathrm{t}}$ and $\mathrm{CO}_{\mathrm{t}}$ may influence $\mathrm{LLP}_{\mathrm{t}}$. Table 5 is the regression result of Eq.(1). If we use $\mathrm{CO}_{t}$ as the only explanatory variable to $\mathrm{LLP}_{\mathrm{t}}$. The $\mathrm{R}$ square of Eq.(1) is about 0.946. After adding the $\mathrm{B}_{-} \mathrm{BAL}_{t}$, the adjusted $\mathrm{R}$ square of Eq.(1) increases to 0.950. The coefficient of $\mathrm{CO}_{\mathrm{t}}$ and $\mathrm{B} \_B A L_{t}$ is $1.000(\mathrm{p}<0.01)$ and $-0.164(\mathrm{p}<0.01)$, respectively. It implies that with one unit of loan charge-offs, bank managers will replenish the allowance for bad debts to the original amount before loan charge-offs. In addition, the coefficient of $B \_B A L_{t}$ is negative $(-0.164)$ which indicates that one unit increase of $B \_B A L$ will cause $L_{-} P_{t}$ to decrease 0.164 units.

In practice, banks in Taiwan are required by regulation to classify assets to five categories based on risk assessment. Bank managers must follow the regulations to accomplish loan loss provisions every year accordingly. As we can see in Table 5, one unit of increase in $\mathrm{CO}_{\mathrm{t}}$ will cause one unit of increase in $\mathrm{LLP}_{\mathrm{t}}$. It implies that bank

\footnotetext{
${ }^{1}$ We use the factors including the beginning balance of allowance for bad debts, loan charge-offs, the ending balance of allowance for bad debts, loan charge-offs in previous year, total uncollectible loans, interest receivable, total amount of credit loans, loan loss provisions in the previous year and assets
} 
managers intend to maintain same level of loan loss provisions during our sample period. The difference between the actual provision of loan losses and expected provision according to the specific provision proportion on potential uncollectible loans (grouping by risk assessment) is what we call "discretionary loan loss provisions".

Table 5: Regressing Results of Eq.(1)

\begin{tabular}{|c|c|c|c|}
\hline Variables & Estimated coefficient & t-value & p-value \\
\hline Constant & 0.339 & 1.709 & 0.089 \\
\hline B_BAL $t$ & -0.164 & -3.645 & 0.000 \\
\hline $\mathrm{CO}_{\mathrm{t}}$ & 1.000 & 45.282 & 0.000 \\
\hline Sample size & & & \\
\hline F-value & 164 & & \\
\hline Adjusted $\mathrm{R}^{2}$ & 1,548 & & \\
\hline
\end{tabular}

Significant at the $1 \%$ level; ${ }^{* *}$ Significant at the 5\% level; ${ }^{*}$ Significant at the $10 \%$ level See Table 3 for variable definitions.

Besides, the Durbin-Watson test shows the statistic D is 1.897. To avoid potential autocorrelation, we use the Cochrane-Orutt procedure to eliminate the problem of autocorrelated errors. Table 6 shows that the regression result of Eq.(1) has no autocorrelation problem. If bank managers intend to raise earnings, they may underestimate the risk of specific loans and lift up the rating of potential uncollectible loans in order to decrease the provision of loan losses.

Table 6: The Regressing Result of Eq.(1) under the Cochrane-Orutt Procedure

\begin{tabular}{|c|c|c|c|}
\hline Variables & Estimated coefficient & t-value & p-value \\
\hline Constant & 0.362 & 1.842 & 0.067 \\
\hline B_BAL $_{t}$ & -0.183 & -3.979 & 0.000 \\
\hline $\mathrm{CO}_{\mathrm{t}}$ & 1.004 & 45.514 & $0.000^{\cdots \cdots n}$ \\
\hline Sample size & 163 & & \\
\hline F-value & 1,523 & & \\
\hline Adjusted $\mathrm{R}^{2}$ & 0.949 & & \\
\hline
\end{tabular}

Significant at the $1 \%$ level; ${ }^{* *}$ Significant at the $5 \%$ level; ${ }^{*}$ Significant at the $10 \%$ level See Table 3 for variable definitions.

\section{Hypothesis Tests}

We use the result in Table 6 to calculate the residual as the surrogate of discretionary loan loss provisions. Incorporating ownership status $\left(G_{\text {OVERN }}\right)$, the type of bank $\left(\mathrm{CATA}_{t}\right)$ and bank size $(\operatorname{lnASSET})$ into Eq. $(2)$ as control variables, we use earnings before loan loss provisions at the end of the year $\left(\mathrm{BP}_{-} \mathrm{EARN}_{\mathrm{t}}\right)$, one-year-ahead earnings $\left(E A R N_{t+1}\right)$, capital ratio at the end of the year $\left(\mathrm{BIS}_{\mathrm{t}}\right)$, total non-performing loans $\left(\mathrm{NPL}_{\mathrm{t}}\right)$, non-performing loans ratio at the end of the year $\left(R_{-} N_{P L}\right)$ and bad debts coverage ratio $\left(R_{-}\right.$COVER $)$as explanatory variables to test our hypotheses.

Table 7 exhibits the descriptive statistic of explanatory variables as well as control variables on Eq.(2). The standard deviation of BP_EARN ${ }_{t}, E_{\text {EAN }} \mathrm{t}_{t+1}$ and $\mathrm{NPL}_{\mathrm{t}}$ is 7.12, 7.59 and 19.62. But the mean of those variables is 6.21, 0.80 and 17.17, respectively. It implies a substantial divergence in earnings performance and non-performing loans between banks. Table 8 shows the regression results of Eq.(2). 
Table 7: Descriptive Statistic of variables in Eq. (2)

\begin{tabular}{|c|c|c|c|c|c|}
\hline Variables & Sample Size & Minimum & Maximum & Mean & S.D \\
\hline DLLP $_{t}$ & 130 & -7.18 & 8.51 & 0.20 & 1.63 \\
\hline $\ln \mathrm{ASSET}_{\mathrm{t}}$ & 130 & 3.73 & 7.60 & 5.83 & 0.82 \\
\hline $\mathrm{BP}_{-} \mathrm{EARN}_{\mathrm{t}}$ & 130 & -20.41 & 32.50 & 6.21 & 7.12 \\
\hline $\left.\mathrm{EARN}_{\mathrm{t}+1}\right)$ & 130 & -36.82 & 17.67 & 0.80 & 7.59 \\
\hline $\mathrm{BIS}_{\mathrm{t}}$ & 130 & 1.04 & 19.77 & 10.31 & 2.38 \\
\hline $\mathrm{R}_{-} \mathrm{NPL}_{\mathrm{t}}$ & 130 & 0.82 & 30.25 & 5.95 & 4.89 \\
\hline$\overline{N P L}_{t}$ & 130 & 0.29 & 95.51 & 17.17 & 19.62 \\
\hline $\mathrm{R}_{\text {CCOVER }}$ & 130 & 0.09 & 7.68 & 0.39 & 0.67 \\
\hline Sample Size & 130 & & & & \\
\hline
\end{tabular}

Significant at the $1 \%$ level; ${ }^{* * *}$ Significant at the $5 \%$ level; ${ }^{*}$ Significant at the $10 \%$ level

DLLP: discretionary loan loss provisions in year $\mathrm{t}$

$\ln \mathrm{ASSET}_{\mathrm{t}}$ : natural logarithm of total assets at the end of the year

BP_EARN $\mathrm{t}_{t}$ : earnings before loan loss provisions at the end of the year

EARN $_{t+1}$ : one-year-ahead earnings

BIS $_{\mathrm{t}}$ : capital ratio at the end of year $\mathrm{t}$

$\mathrm{NPL}_{\mathrm{t}}$ : total non-performing loans in year $\mathrm{t}$

$\mathrm{R}_{\mathrm{N}} \mathrm{NPL}_{\mathrm{t}}$ : non-performing loans ratio at the end of year $\mathrm{t}$

$\mathrm{R}_{\text {_COVER }}$ : bad debts coverage ratio in year $\mathrm{t}$ (i.e. loan loss provisions at the end of the year over total non-performing loans)

Table 8: Regressing Results of Eq.(2)

\begin{tabular}{|c|c|c|c|c|c|}
\hline Variables & $\begin{array}{l}\text { Estimated } \\
\text { coefficient }\end{array}$ & $\begin{array}{l}\text { Standardized } \\
\text { coefficient }\end{array}$ & $\mathbf{t}$ & $p$ value & VIF \\
\hline Constant & 7.147 & - & 2.749 & $0.007^{\pi}$ & - \\
\hline GOVERN $_{t}$ & -0.571 & -0.161 & -1.005 & 0.317 & 4.829 \\
\hline CATA $_{t}$ & 0.582 & 0.153 & 1.267 & 0.208 & 2.425 \\
\hline $\ln \mathrm{ASSET}_{\mathrm{t}}$ & -1.539 & -0.771 & -3.544 & $0.001^{\pi}$ & 7.876 \\
\hline BP_EARN $_{t}$ & 0.086 & 0.377 & 3.112 & 0.002 & 2.440 \\
\hline EARN $_{t+1}$ & 0.063 & 0.293 & 2.703 & $0.008^{\prime \prime}$ & 1.953 \\
\hline BIS $_{\mathrm{t}}$ & 0.044 & 0.064 & 0.703 & 0.484 & 1.374 \\
\hline $\mathrm{R}_{\mathrm{NPL}} \mathrm{t}$ & -0.018 & -0.053 & -0.421 & 0.674 & 2.665 \\
\hline $\mathrm{NPL}_{\mathrm{t}}$ & 0.062 & 0.748 & 3.923 & $0.000^{*}$ & 6.041 \\
\hline R_COVER & -0.044 & -0.018 & -0.227 & 0.821 & 1.086 \\
\hline Sample Size & 130 & & & & \\
\hline F-value & 5.133 & & & & \\
\hline Adjusted R2 & 0.224 & & & & \\
\hline
\end{tabular}

Significant at the $1 \%$ level; ${ }^{* *}$ Significant at the 5\% level; ${ }^{*}$ Significant at the $10 \%$ level

GOVERN $_{\mathrm{t}}$ : an indicator variable equal to 1 when the bank's ownership is controlled mainly by government and 0 otherwise CATA $_{t}$ : an indicator variable equal to 1 when the bank is classified as a commercial bank and 0 otherwise

See Table 7 for definitions of other variables.

In Table 8, the variance inflation factor (VIF) for all variables is all smaller than 10 , therefore, the multicollinearity between variables is not serious. The coefficient of BP_EARN $\mathrm{B}_{\mathrm{t}}(0.086, \mathrm{p}<0.01)$ indicates positive relation between earnings before loan loss provisions and discretionary loan loss provisions. It suggests that bank managers intend to raise the provision of loan losses to write off bad debts as well as reduce the non-performing loans ratio. The coefficient of $\mathrm{EARN}_{\mathrm{t}+1}(0.063, \mathrm{p}<0.01)$ means positive relation between one-year-ahead earnings and discretionary loan loss provisions. It suggests that managers may use discretionary loan loss provisions to lift one-year-ahead earnings up intentionally. Finally, the coefficient of $\mathrm{NPL}_{t}(0.062, \mathrm{p}<0.01)$ shows positive relation between non-performing loans and discretionary loan loss provisions. It suggests when the amount of non-performing loans increases, bank managers may increase the provisions of loan losses in order to reduce the non-performing loans ratio. We conclude that the hypotheses $\mathrm{H}_{1 \mathrm{a}}, \mathrm{H}_{1 \mathrm{~b}}$ and $\mathrm{H}_{3 \mathrm{~b}}$ are supported. As for $\mathrm{H}_{2}, \mathrm{H}_{3 \mathrm{a}}$ and $\mathrm{H}_{3 \mathrm{~b}}$, the coefficients on $\mathrm{BIS}_{\mathrm{t}}, \mathrm{R} \_\mathrm{NPL}_{\mathrm{t}}$ and $\mathrm{R} \_\mathrm{COVER}_{\mathrm{t}}$ are insignificant at conventional levels. Thus, the results in Table 8 do not support the hypotheses $\mathrm{H}_{2}, \mathrm{H}_{3 \mathrm{a}}$ and $\mathrm{H}_{3 \mathrm{~b}}$. 
As for the other control variables, the coefficient of $\operatorname{lnASSET}_{\mathrm{t}}(-1.539, \mathrm{p}<0.01)$ indicates that the larger the bank is, the smaller the discretionary loan loss provisions are. But our results do not find significant evidence about the influence of both GOVERN $\mathrm{N}_{\mathrm{t}}$ and $\mathrm{CATA}_{\mathrm{t}}$ on discretionary loan loss provisions.

\section{Analysis On Earnings Management}

The deviation between the actual provisions of loan losses and the estimated loan loss provisions calculated by regression Eq.(2) represents the discretionary loan loss provisions. No matter what the sign of the discretionary loan loss provision is, we use the absolute value of the deviation as a surrogate of earnings management. We further divide the sample into two groups according to the mean of the absolute value of DLLP $_{t}$ and each explanatory variable respectively. Table 9 exhibits the results of the t-test.

Table 9: Results of the t-test for ABS(DLLP $)$ and Explanatory Variables

\begin{tabular}{|c|c|c|c|}
\hline Variables & Group & Mean of ABS(DLLP $\left.{ }_{t}\right)$ & p value \\
\hline \multirow{2}{*}{$\mathrm{BP}_{-} \mathrm{EARN}_{\mathrm{t}}$} & High & 1.8303 & 0.000 \\
\hline & Low & 0.6239 & \\
\hline \multirow{2}{*}{$\mathrm{EARN}_{\mathrm{t}+1}$} & High & 1.1398 & 0.194 \\
\hline & Low & 0.8394 & \\
\hline \multirow[b]{2}{*}{$\mathrm{BIS}_{\mathrm{t}}$} & High & 1.0652 & 0.692 \\
\hline & Low & 0.9838 & \\
\hline \multirow{2}{*}{ R_NPL $L_{t}$} & High & 1.2734 & 0.112 \\
\hline & Low & 0.9210 & \\
\hline \multirow{2}{*}{$\mathrm{NPL}_{\mathrm{t}}$} & High & 1.7319 & 0.000 \\
\hline & Low & 0.7624 & \\
\hline \multirow{2}{*}{$\mathrm{R}_{-} \mathrm{COVER}_{\mathrm{t}}$} & High & 1.2004 & 0.232 \\
\hline & Low & 0.9417 & \\
\hline
\end{tabular}

Significant at the $1 \%$ level; ${ }^{* *}$ Significant at the 5\% level; ${ }^{*}$ Significant at the $10 \%$ level

ABS $\left(\mathrm{DLLP}_{\mathrm{t}}\right)$ : the absolute value of the earnings before loan loss provisions in year $t$ See Table 7 for the definitions of other variables.

Our findings in Table 9 indicate that the means of ABS(DLLP $)$ in high BP_EARN $\mathrm{N}_{\mathrm{t}}$ group and in high $\mathrm{NPL}_{\mathrm{t}}$ group are larger than those in low BP_EARN $\mathrm{t}_{\mathrm{t}}$ group and in low $\mathrm{NPL}_{\mathrm{t}}$ group. Namely, bank managers intend to use discretionary loan loss provisions to influence reported earnings when they have high earnings before loan loss provisions or high non-performing loans.

\section{SUMMARY AND CONCLUSION}

Prior studies about loan loss provisions mainly focus on the effects of discretionary loan losses provisions on earnings management, capital management, taxes management and stock return. We use financial data of the Taiwanese banks through the period of 1999-2004 to investigate the factors which may affect the discretionary provision of loan losses. Our findings provide evidence of a positive link between discretionary loan loss provisions and the earnings before loan loss provisions, as well as one-year-ahead earnings and non-performing loans. When the earnings before loan loss provisions increase, bank mangers may increase discretionary loan loss provisions so as to alleviate the pressure of high non-performing loans ratios. Under the same consideration, bank managers may raise the discretionary loan loss provisions when non-performing loans are at a high level. Besides, when the one-year-ahead earnings increase, it may be caused at the expense of current year's earnings. But we do not find evidence on the relation between discretionary loan loss provisions and capital ratio, non-performing loans ratio and the bad debts coverage ratio.

Finally, our findings indicate a positive relation between the absolute value of discretionary loan loss provisions and the earnings before loan loss provisions, as well as non-performing loans. This suggests that banks with high earnings before loan loss provisions and high non-performing loans may intend to increase or decrease discretionary loan loss provisions for the purpose of earnings management. 


\section{REFERENCES}

1. Ahmed, A.S., C. Takeda, and S. Thomas, 1999. Bank loan provision: a reexamination of capital management and signaling effects. Journal of Accounting and Economics, 28(1): 1-25.

2. Anandarajan, A., I. Hasan, and C. McCarthy, 2007. Use of loan loss provisions for capital, earnings management and signalling by Australian banks. Accounting \& Finance, 47(3): 357-379.

3. Beatty, A., K. Bin, and K.R. Petroni, 2002. Earnings management to avoid earnings declines across publicly and privately held banks. Accounting Review, 77(3): 547-570.

4. Beatty, A., S.L. Chamberlain, and J. Magliolo, 1995. Managing financial reports of commercial banks: the influence of taxes, regulatory capital, and earnings. Journal of Accounting Research, 33(2): 231-261.

5. Beaver, W.H., and E.E. Engel, 1996. Discretionary behavior with respect to allowance for loan losses and the behavior of securities prices. Journal of Accounting and Economics, 22(1-3): 177-206.

6. Bernard, V.L. and D.J. Skinner, 1996. What motivates managers' choice of discretionary accruals? Journal of Accounting and Economics, 22(1-3): 313-325.

7. Chen, Y., 2002. Empirical study on banking industry bad debts management in Taiwan, International Journal of Accounting Studies, 21(4): 1-17.

8. Clinch, G., and J. Magliolo, 1993. CEO compensation and components of earnings in bank holding companies. Journal of Accounting and Economics, 16(1-3): 241-272.

9. Collins, J.H., D.A. Shackelford, and J.M. Wahlen, 1995. Bank differences in the coordination of regulatory capital, earnings and taxes. Journal of Accounting Research, 33(2): 263-291.

10. Dechow, P.M., and R.G. Sloan, 1991. Executive incentives and the horizon problem. Journal of Accounting and Economics, 14(1): 51-89.

11. Elliott, J., J. Hanna, and W. Shaw, 1991. The evaluation by the financial markets of changes in bank loan loss reserve level. Accounting Review, 66(4):847-861.

12. Eng, L. and S. Nabar, 2007. Loan loss provisions by banks in Hong Kong, Malaysia and Singapore. Journal of International Financial Management \& Accounting, 18(1): 18-38.

13. Gabor, M., 1985. Management incentives to report forecasts of corporate earnings. Unpublished Ph.D. dissertation, The City University of New York

14. Greenawalt, M., and J. Sinkey, 1988. Bank loan loss provisions and the income smoothing hypothesis: an empirical analysis, 1976-1984. Journal of Financial Services Research, 1(4): 301-318.

15. Griffin, P., and S. Wallach, 1991. Latin American lending by major banks: the effects of disclosure about nonaccrual loans and loan loss provisions. Accounting Review, 66(4): 830-846.

16. Healy, P.M., 1985. The effects of bonus schemes on accounting decisions. Journal of Accounting and Economics, $7(1 / 2 / 3)$ : 85-107.

17. Healy, P.M., and J.M. Wahlen, 1999. A review of the earnings management literature and its implications for standard setting. Accounting Horizon, 13(4): 365-383.

18. Kanagaretnam, K., G.J. Lobo, and R. Mathieu, 2003. Managerial incentives for income smoothing through bank loan loss provisions. Review of Quantitative Finance \& Accounting, 20(1): 63-80.

19. Kanagaretnam, K., G.J. Lobo, and D.H. Yang, 2004. Joint tests of signaling and incomes smoothing through bank loan loss provisions. Contemporary Accounting Research, 21(4): 843-884.

20. Lewellen, W.G., T. Park, and B.T. Ro, 1996. Self-serving behavior in managers' discretionary information disclosure decisions. Journal of Accounting and Economics, 21(2): 227-251.

21. Lin, H., and Y. Chen, 1997. An empirical study on the extent capital adequacy ratio measures Taiwan commercial bank shareholder risks. The Chinese Accounting Review, 30: 181-221.

22. Liu C., and S.G. Ryan, 1995. The effect of bank loan portfolio composition on the market reaction to and anticipation of loan loss provisions. Journal of Accounting Research, 33(1): 77-94.

23. Liu, S., 1995. On the signaling incentives of loan loss provision recognized by banks. The Chinese Accounting Review, 29(Oct.): 223-255.

24. McNichols, M., and G.P. Wilson, 1988. Evidence of earnings management from the provision for bad debts. Journal of Accounting Research, 26(3): 1-31.

25. Moyer, S., 1990. Capital adequacy ratio regulations and accounting choices in commercial banks. Journal of Accounting and Economics, 13(2): 123-154.

26. Schipper, K., 1989. Commentary on earnings management. Accounting Horizons, 3(4): 91-102.

27. Scholes, M., G.P. Wilson, and M.A. Wolfson, 1990. Tax planning, regulatory capital planning and financial reporting strategy for commercial banks. Review of Financial Studies, 3(4): 625-650.

28. Shrieves, R.E., and D. Dahl, 2003. Discretionary accounting and behavior of Japanese banks under 
financial duress. Journal of Banking and Finance, 27(7): 1219-1243.

29. Wahlen, J.M., 1994. The nature of information in commercial bank loan lose disclosure. Accounting Review, 69(3): 455-478.

30. Watts, R.L., and J.L. Zimmerman, 1978. Towards a positive theory of the determination of accounting standards. Accounting Review, 53(1): 112-134.

\section{NOTES}

